\title{
DRAMATIC MONOLOGUE IN ROBERT BROWNING'S POEM “ANDREA DEL SARTO”
}

\author{
FadhillahWiandari \\ IAIN Langsa \\ fadhillabwiandari@yahoo.co.id
}

\begin{abstract}
Robert browning and the form of poetry known as "dramatic monologue" inevitably go togather. It is already made known that dramatic monologue is esssentially a narrative spoken by a single character. We are to imagine that it is being listened to but never answered; it is a dialogue of which we are to hear only one side. It gains added effect and dimensions through the character's comments on his own story and the circumtances in which he speaks. It is through the single character's speech that Browning present the plot, characters and scenes. It is through the words of Andrea that the reader can feel the presence of the plot, characters and scenes. This article tries to describe how Robert Browning handles his three objects in writing dramatic monologue through his poem entitled Andrea Del Sarto.
\end{abstract}

\section{Keyword}

Dramatic monologue, poem, objective poetry.

\section{INTRODUCTION}

Robert Browning and the form of poetry called "dramatic monologue" inavitably go together. The dramatic monologue is essentially a narrative spoken by a single character. It gains added effects and dimensions through the character's comments on his own story and circumtances in which he speaks (Sen: 2000). M.H Abrams (2002) remarks that the dramatic monologue has the following characteristics: first, a single person, who is not the poet himself, utters the entire poem in a specific situation at a critical moment. Second, this person addresses and interacts with one or more other people; but we know of the auditors' presence and what they say and do only 
from clues in the discourse of a single speaker. Third, the monologue is so organize that its focus is on the temprament and the character that the dramatic speaker unintentionally reveals in the course of what he says.

In the dramatic monologue the reader can infer or judge the intelligence and honesty of the narrator and asses the value of views expressed. The form also gives the poet the opportunity to be technically impersonal like a dramatist. However, the salient featuresof the dramatic monologue can be understood better if we compare the dramatic monologue with soliloquy. Since the dramatic monologue is a narrative spoken by a single person; the form seems to have affinity with the soliloquy, man talking to himself of private debate. However, we should not forget that the root meaning of the term "monologue" is a single man's conversation. Of course, that may sound slightly paradoxical because conversation by its very nature means a talk between two persons. The paradox is resolved when we realized that in the dramatic monologue, though the active speech is ascribed to a single person, the presence and the reactions of other person are conveyed naturally in the course of the single man's talk. The listener does not actively interrupt the current of speech. Thus, the dramatic monologue, unlike the soliloquy, implies the presence of some other character or characters, listening and reacting. In a soliloquy, the speaker deliver his own thoughts, uninterrupted by the objections or the proportions of other persons. In a dramatic monologue; however, the reactions of the listener, or other persons, are woven into a speaker's word.

Andrea del Sarto is one of the greatest dramatic monologue of Browning. The poem presents a slice from the life of a great painter named Andrea del sarto. The painter is shown in a reflective mood, and as he muses over his failure in art, his very soul is laid bare before the readers. His 
thoughts range over the past and the present, and in this way the complete tragedy of a soul is revealed.

\section{The Poet's Biography}

Browning was born in Camberwell, a suburb of London, England, the first son Robert and Sarah Anna Browning. His father was a man of both fine intellect and character who worked as a well-paid clerk for the bank of England.Browning's paternal grandfather was a wealthy slave owner in St Kitts, west Indies, but Browning's father was an abolitionist. Browning's father had been sent to the west Indies to work on a sugar plantation. Revolted by the slavery there, he soon returned to England. Browning's mother was a musician. He had one sister, Sarianna. It is rumored that Browning's grandmother, margaret Tittle, was a Jamaican-born mulatto who had inherited a plantation in St Kitts.

Browning was a fast lerner, and by the age of fourteen he wa fluent in French, Italian and Latin as well as his native English. He became a great admirer of the romantic poets, especially Shelley. Following the precedent of Shelley, Browning become an atheis and vegetarian, both of he gave up later. At the age of sixteen, he attended University Collage London but left after his first year. His mother staunch evangelical faith prevented his studying at either Oxford University or Cambridge University; both then open only to members of the church of England. He had substantial musical ability and composed arrangements of various songs.In 1845, Browning met Elizabeth Barret, who lived as a semi-invalid and virtual prisoner in her father's house in Wimpole street. Gradually a significant romance developed between them, leading to their secret marriage and flight on September 12, 1846. (The marriage was initially secreat because Elizabeth's father disapproved of 
marriage for any of his children). From the time of their marriage, they lived in Italy, first in Pisa, and then, within a year, finding an apartment in Florence at Casa Guidi (now a musium to their memory). Their only child, Wiedeman Barret Browning, nick name "Penini" or "Pen", was born in 1849. In these years Browning was fascinated by and learned hugely from the art and atmosphere of Italy. He would, in later life, say that 'italy was my university'. Browning was also bought a home in Asolo, in the Veneto outside venice, and in a cruel irony he died on the day that the Town Council approved the purchase.

His wife died in 1861 and he died in 12 December 1889 at his son's home Ca' Rezzonico in Venice, the same day as Asolando wan published, and was buried in Poets' corner in Westminister Abbey. His grave now lies immediately adjacent to that of Alfred Tennyson.

\section{Summary of the Poem}

This poem represents yet another of Brownings' dramatic monologue spoken in the voice of historical Renaissance painter. Andrea Del Sarto, like Fra Lippo Lippi, lived and worked in Florence, Albeit a little later than Lippo, and was later appointed court painter by Francis, the King of France.

Under the nagging influence of hid wife Lucrezia,to whom he speak in this poem, he left the Franch court for Italy but promise to return; he took with him some money that Francix has given him to purchase Italian artwork for the court, and also the money advance to him for his own comissioned paintings. However, he spent all of his money on a house of himself and his wife in Italy and never returned to France.This poem find Andrea in the house he has bought with the stolen money, as he thinks back on his career and laments that his wordly concerns have kept him from fulfilling his 
promoise as an artist. As he and Lucrezia sit at their window, he talks to her at his relative successes and failures: although Michelangelo (here, Michel agnolo) and raphael (Rafael) enjoyed higher inspiration and better petronageand lacked nagging wives-he is the better craftsman, and he points outto her the problems with the Great Masters' work. But while Andrea succeeds technically where they do not (thus his title "the faulltless painter"), their work ultimately triumphs for its emotional and spiritual power.

Andrea now finds himself in the twilight of his career and his marriage: Lucrezia’s Cousin- probably her lover-keeeps whistling for her to come; she apparently either owes the man gambling debts or has promised to cover his own. The fond weary Andrea gives her some money, promises to sell paintings to pay off her debts, and sends her away to her "cousin' while he remains to sit quietly and dream of painting in heaven.

\section{CHARACTERISTICS OF ROBERT BROWNING'S POETRY}

\section{Representing his character in moments of tense drama}

Browning is passionately interested in all form of human nature. He is eager to know exactly how men and woman think and feel, therefore his chief work is in spiritual portraiture. Browning represents them usually in moments of tense drama, and does not forget their physical presence. $\mathrm{He}$ had the zest of the novelist for every kind of detail, and to his strong, wholesome good sense nothing comes amiss in the way of vice or madness or abnormality. Whatever is or has been human is his province, and he has the gusto of an antiquary in digging into the dust of the past.

\section{2. dealing with the imaginary ones and historical persons}


He manage to allow many of his imagined person to be pretty much themselves. In writing andrea Del sarto, the poet was more than usually faithful to his sources, and the result is a triumphant portrait of the painter. Andrea says what the reader is convince he would say. But, unfortunately he says more. He accepts the doctrine of compensation: if things do not go well in this world, thing will be proportionately better in the next.

\section{Not possesing the objectivity of a dramatist}

Browning cannot throw large and varied groups of people togather. In all the words which his characters utter we seem to hear the ring of Browning's own voice. He is less a dramatic than an exhibitor, an interpreter of single dramatic situations. In presenting these single situations, Browning's power is absolute; here he works with the most graphic vividness, and with the compression of meaning which crowds into a few lines the implication of life-time.

\section{Using pure dramas, dramatic narrative, and dramatic lyric}

In three form - pure drama, dramatic narrative, and dramatic lyric he gave the history of hundreds of souls; or, if not their whole history, at least some crucial moment of it, when its issues trembled in the balance and dipped toward good or evil. In his earlier life, he made many attemps to present these crucial moment in dramas intended for the stage, but but the form was not perfectly suited to his peculiar cast.

\section{Clergy, as a rule, not drawn from the loftiest type}

The bishop ordering his tomb makes the monk in the Spanish cloister shows the weak points of "enclosed orders". It is in The Ring and 
the book, in the character of caponsacchi, the soldier-priest who tries in vain to save pompilia that he shows the noblest type of christisn service.

\section{Presenting a large number of memorable character}

Ithas been suggested that, in his power over character, Browning is second only to shakespeare. Browning has presented something over eighty memorable characters, of which about thirty are women. These numbers include not only principals but figures like Gigadibs and Elvire.

\section{The Use of Dramatic Monologue Depicted in the Poem}

Robert Brownig and the form of poetry known as "dramatic monologue" inevitaby go togather. It is alredy known that dramatic monologue is essentially a narrative spoken by a single character. It gains added effect and dimension through the character's comments on his own story and the circumtances in which he speaks. It is through the single character's speech that browning presents the plot, characters and scenes.

\section{To Present the Plot}

Plot may be defined as a story itself with all the procedures. It deals with the organization of certain events, situations and episodes in a narrative or play.In the poem, Browning skillfully makes use dramatic monologue to present the plot. This poem opens at a section from Andrea's life in which Andrea reveals his own basic weakness. He begs his wife to sit by him for an evening and bribes her for it.

Sit down and all shall happens as tou wish

You turn your face, but does it bring your heart?

I'll work then for your friend's friend, never fear

Fix his own time, accept too his own price

And shut the money into this small hand, 
(Lines: 3-8)

From the lines quoted above, it can be seen that Andrea promises to paint for her "friend" the next day, but her company would inspire him to paint better so that he can earn more, and give her more money to hand it over to her "friend" that he might discharge his debts. Whatever money he gets, he will shut it in her small hand, i.e. he will give the money to her and she may spend it in the way she likes. The lover is under debts.

\section{To Present the Character}

Character is a person or a figure, man and woman, in whose life events and incidents take place. Without character, action cannot proceed, remain unimportant, be rather meaningless. In Andrea del Sarto, Browning makes use the dramatic monologue to show andrea as the speaker. It is through the words of Andrea that the reader can feel the presence of the listener and other character in the poem.The presence of Lucrezia as the listener in the poem can be felt at the opening of the poem.

But do not letus quarrel any more

No, my Lucrezia ; bear with me foe once :

"Sit down and all shall happen as you wish

You turn your face, but does it bring your heart?

(Lines: 1-4)

From the lines qouted above, it can be seen that Andrea, the speaker, addresses his speech to someone named Lucrezia, who become the listener in the poem. From the first line of the poem: "but do not let us quarrel anymore", the reader can see that Andrea has been quarreling with his wife named Lucrezia, and Andrea asks her to be patient with him and do not 
quarrel anymore. He will do as she wishes if she is ready to sits down beside him for a while. From the line: "you turn your face, but does it bring your heart?", it can also be inferred that Lucrezia responses Andrea's request by turning her face to him. It means that the monologue is clearly seen in the poem.

\section{To Present the Scene}

Scene is the structure on which a spectatcle or play is exhibited; the part of the theatre in which the acting is done, with its adjunct and decorations; the stage.

From the words of Andrea, the reader can see that the scene is in Andrea's studio in Fiesole in which Andrea asks his wife named Lucrezia to sit by the window in other that they can enjoy the scenery of fiesole from their window.

As if-Forgive now - should you let me sit

Here by the window with your hand in mine

And look a half hour fort on Fiesole

Both of one mind, as married people use

Quietly, quietly, the evening through,

(Lines: 13-17)

From the lines quoted above, it can be seen that Andrea request his wife Lucrezia to sit by the window in his studio in Fiesole, holding with her hand in his. He would like to spend half an hour or so looking out on the town of Fiesole in the company of his wife. Fiesole is the name of a small but famous city of Italy. It is situated on the top of hill, about three miles to the west of Florence. 


\section{CONCLUSION}

The poet has three objects in writing the dramatic monologue in this poem, i.e. they are to present plot, character and scene in the speech of single character.We are to imagine it is being listened to but never answered; it is a dialogue of which we are to hear only one side. The scene in which the story tajes place is mainly in andrea's studio. It is in an autumn evening in Fiesole, Italy, in King Franci's palace, the scene moves to Fontainebleau, in France.

\section{REFERENCE}

Abrams, M.H. 2014. A glossary of literary term 11th edition. India: Macmillan India Limited.

Birch, Dinar and Hooper, Katy. 2013. The Oxford Companion to English Literature. New York: Oxford University Press.

Bode, Carl. 2003. Highlights of American Literature. Washington DC: USIS.

Cox, James M. 2004. Robert Browning: A collection of critical essays. USA: Pretentice-hall, Inc.

Sen, S.. 2010. Robert Browning Selected Poem: A Critical Evaluation. India: unique Publisher.

Tilak, Rughukul. 1993. Robert Browning: studies in Poets. New Delhi. Rama Brothers.

Wiandari, Fadhillah. 2010. An analysis of the use of dramatic monologuein Robert Browning's poem "Andrea del sarto". Islamic University of North sumatra. 